трансформацией преступности, а и внедрением новых механизмов (европейских стандартов) в практику правоприменения, необходимостью использования криминалистических знаний в различных юрисдикционных процессах.

Ключевые слова: криминалистика, криминалистические знания, криминалистические средства, задачи криминалистики, парадигма криминалистики, глобальные угрозы, глобализация преступности, информация, информационная война, противодействие преступности.

\title{
CRIMINALISTICS AS A SYSTEM OF SCIENTIFIC KNOWLEDGE IN GLOBAL THREATS AND TRANSFORMATION OF CRIME
}

\section{Shepitko V. Yu.}

The functional purpose of criminalistic knowledge in the conditions of global threats and significant change of crime is considered. In the new conditions of the development of society, criminalistics is called upon to develop the latest means of counteracting crime. A separate direction in criminalistics should be the protection of information sources and the problems of information security. The role of the usage of criminalistic knowledge in counteracting information challenges and information (hybrid) war is emphasized. The process of crimes investigation and judicial proceedings is defined as "the struggle for information". The possibility of obtaining objective information depends on the criminalistic means involved. Criminalistic tools (techniques, methods, technologies, recommendations) should correspond to informational manifestations, successfully counteract crime. The importance of introducing the practice of criminalistic knowledge application, the latest scientific, technical and other means of collecting evidence in global armed conflicts has been argued. Attention is paid to changing the tasks that are put in front of criminalistics. It has been suggested that there are criminalistics tasks at the following levels: strategic and tactical; theoretical informative and pragmatic (applied). Changing the tasks of criminalistics is caused not only by the transformation of crime, but also by the introduction of new mechanisms (European standards) into the practice of law enforcement, the need to use criminalistic knowledge in various jurisdictional processes.

Keywords: criminalistics, criminalistic knowledge, criminalistic tools, tasks of criminalistics, paradigm of criminalistics, global threats, globalization of crime, information, information war, crime counteraction.

DOI: https://doi.org/10.32353/khrife.2018.02

УДК 343.98

$\boldsymbol{B}$. A. Журавель, головний учений секретар Національної академії правових наук України, доктор юридичних наук, професор, академік НАПрН України E-mail: zhur.crim@gmail.com

\section{ОКРЕМІ ВЧЕННЯ В СТРУКТУРІ ЗАГАЛЬНОЇ ТЕОРІЇ КРИМІНАЛІСТИКИ}

Розглянуто концептуальні підходи до формування й застосування окремих криміналістичних учень (теорій) як наукових конструкцій, щуо становлять основу структури загальної теорії криміналістики та визначають

(C) Журавель В. А., 2018 
рівень розроблення теоретико-методологічної бази изієї науки. Надано авторське розуміння поняття «окреме криміналістичне вчення (теорія)» і висловлено пропозииї̈ стосовно систематизаиії окремих криміналістичних учень, їх місия в структурі загальної теорії криміналістики. Зазначено, щео сучасна система окремих криміналістичних учень (теорій) є динамічною і ї̈ вдосконалення зумовлене потребами судової та слідчої практики, розвитком суміжних галузей знань, загальної теорії й самих окремих криміналістичних учень, зміною зв'язків $і$ залежностей між ними. Визначено критерії, яким має відповідати окреме криміналістичне вчення (теорія). Виокремлено дискусійні питання щодо досліджуваної проблеми, окреслено шляхи оптимізаиії наукових розробок у иій ичарині знань.

Ключові слова: загальна теорія криміналістики, структура загальної теорії криміналістики, окремі криміналістичні вчення (теорії), систематизачія окремих криміналістичних учень (теорій).

Постановка проблеми. Загальна теорія криміналістики як система іiі світоглядних принципів, теоретичних концепцій, категорій і понять, методів та зв'язків, визначень і термінів слугує методологічною основою криміналістики ${ }^{1}$. У структурі загальної теорії криміналістики основне місце посідають окремі криміналістичні вчення. Загалом загальну теорію криміналістики можна розглядати як систему різного рівня узагальнення та спрямованості окремих криміналістичних учень, які в сукупності утворюють теоретико-методологічну базу цієї науки.

Актуальність теми дослідження. Розробка концептуальних підходів до формування й застосування окремих криміналістичних учень (теорій), визначення їх місця в структурі загальної теорії криміналістики належить до найбільш актуальних сучасних напрямів криміналістичних досліджень, що визначають стан сформованості її теоретико-методологічної бази. 3'ясування усталених підходів до систематизації окремих криміналістичних учень, визначення їх місця у структурі загальної теорії криміналістики сприятимуть остаточному формуванню сучасної наукової криміналістичної парадигми.

Аналіз останніх досліджень і публікацій. Вагомий внесок у розроблення основ окремих криміналістичних учень (теорій) здійснили такі науковці, як Р. С. Бєлкін, О. М. Васильєв, А. І. Вінберг, О. Ю. Головін, В. Г. Гончаренко, О. О. Ейсман, О. О. Ексархопуло, Г. О. Зорін, 3. І. Кірсанов, В. В. Клочков, В. О. Коновалова, В. С. Корноухов, І. М. Лузгін, Г. А. Матусовський, С. П. Митричев, В. О. Образцов, М. О. Селіванов, В. Г. Танасевич, Б. М. Шавер, В. Ю. Шепітько, М. П. Яблоков. Водночас у сучасній вітчизняній криміналістичній літературі практично відсутні публікації з проблем формування та реалізації окремих криміналістичних учень (теорій), надання їх визначення, з'ясування концептуальних підходів до створення, зокрема, щодо виокремлення критеріїв і умов, за яких відбувається трансформація певних теоретичних побудов в окремі криміналістичні вчення.

${ }^{1}$ Белкин Р. С. Курс криминалистики : в 3 т. Т. 1 : Общая теория криминалистики. Москва : Юристъ, 1997. С. 41. 
Формування цілей статті. Метою статті є з'ясування місця окремих криміналістичних учень у структурі загальної теорії криміналістики, надання пропозицій щодо їх розподілу залежно від ступеня розробленості й узагальнення відображуваних ними елементів об'єкта пізнання, наукової та практичної значущості.

Викладення основного матеріалу. Аксіоматичним є твердження, що окремі наукові теорії досліджують певне коло закономірностей об'єктивної дійсності з числа тих, які вивчає криміналістика в цілому. Генетично вони можуть передувати загальній, а можуть, навпаки, породжуватися останньою ${ }^{1}$. На подовження цієї думки О. О. Ексархопуло зазначає, що в кожній окремій криміналістичній теорії (ученні) розкриваються закономірні зв'язки не всіх «абстрактних» об'єктів ідеалізованої моделі, а лише деякі з них, що, власне, і дозволяє говорити про їх різноманітність. У системі ж криміналістичних теорій відбивається предмет криміналістики в цілому - i тим більш адекватно, чим більше розвинута ця система ${ }^{2}$.

Р. С. Бєлкін, спираючись на положення наукознавства стосовно того, що будь-яка теорія має відповідати вимогам обгрунтованості (робити припущення, базуючись на обмеженій інформації, щодо принципово нових фактів або про майбутній стан об'єктів, що вивчаються), визначеності (описувати результати дослідів термінами цієї теорії), доведеності (установлювати раціональні зв'язки між окремими положеннями теоріі), несуперечності (внутрішній і з отриманими дослідними даними) $)^{3}$, виокремив такі ознаки загальної теорії криміналістики:

- теорія лише тоді може претендувати на значення загальної, якщо вона розповсюджується на весь предмет дослідження, відноситься до нього в цілому, а не до одного з його елементів;

- концепція або система концепцій, що становлять зміст загальної теоpiї, мають відноситися не стільки до явищ, скільки до сутності предмета дослідження, й пояснювати цю сутність;

- загальна теорія, розкриваючи сутність предмета дослідження, повинна виявляти те, що робить цю сутність сталою, - закономірності відносин або зв’язків явищ, тобто закономірності тих процесів, дослідження яких є метою цієї галузі наукового пізнання;

- загальна теорія повинна базуватися на принципах теорії відображення, що має значення наукового світогляду, і відображати «діалектику речі» як основу «діалектики ідеї», а не навпаки;

- загальна теорія повинна являти собою замкнуту понятійну систему, елементи якої тісно зв'язані та органічно переплітаються один з одним ${ }^{4}$.

1 Белкин Р. С. Курс криминалистики : в 3 т. Т. 2 : Частные криминалистические теории. Москва : Юристъ, 1997. С. 19.

2 Эксархопуло А. А. Криминалистическая теория: формирование и перспективы развития в условиях НТР : автореф. дис. ... д-ра юрид. наук : 12.00.09. СПб., 1993. С. 12.

3 Горский Д. П. Научная теория и способы ее обобщения. Вопросы философии. 1966. № 8. С. 43-47.

4 Белкин Р. С. Курс криминалистики : в 3 т. Т. 1 : Общая теория криминалистики. Москва : Юристь, 1997. С. 49. 
Незважаючи на досить одноманітне розуміння сутності загальної та окремих криміналістичних теорій, у той самий час науковці висловлюють багато в чому протилежні судження щодо структури цих теорій як елементів системи криміналістики, а також характеру інтертеоретичних зв'язків між ними. Так, деякі вчені розглядають загальну теорію та окремі вчення як самостійні елементи системи науки криміналістики. Зокрема, В. С. Митричев пропонував у теорії криміналістики виокремлювати дві групи вчень: загальні вчення, тобто такі, які є теоретичним фундаментом науки в цілому або її окремих розділів, і окремі вчення, які складають науковий базис існуючих напрямів криміналістичної діяльності. До загальних учень він відносив криміналістичну методологію, загальні положення техніки, тактики та методики; до окремих вчень - теорію ідентифікації, учення про навички, учення про морфологію, криміналістичну трасологію, криміналістичну субстанціологію1 ${ }^{1}$ В. О. Образцов також виключає зі складу загальної теорії окремі криміналістичні теорії, виокремлюючи в системі криміналістики дві складові: загальну частину - загальну теорію та особливу частину - сукупність окремих учень і теорій².

Усупереч висловленим судженням пропонується розглядати окрему криміналістичну теорію як підсистему загальної теорії криміналістики, а іiі предмет - як елемент, частину, сторону предмета загальної теорії й із цих позицій формувати структуру останньої. Так, О. О. Ексархопуло в структурі загальної теорії криміналістики виділяє три розділи: теоретичні основи криміналістичної науки, криміналістичні теорії злочину, криміналістичні теорії пізнання події злочину в процесі його розкриття, розслідування та попередження ${ }^{3}$.

Водночас слід визнати, що й у прибічників наведеної концепції немає єдиної думки щодо структури побудови й елементного складу загальної теорії криміналістики. Більш того, складність розглядуваної проблеми зумовлює в криміналістів потребу в повторному зверненні до ії дослідження, перегляду власних поглядів. Так, Р. С. Бєлкін спочатку виділяв такі основні елементи загальної теорії криміналістики:

1) вступ до загальної теорії криміналістики (наукознавча частина загальної теорії - предмет науки, іiї завдання, принципи, закони розвитку та місце в системі наукового знання);

2) окремі криміналістичні теорії (учення): учення про механізм злочину, теорія криміналістичної ідентифікації, теорія криміналістичної діагностики, криміналістичне вчення про ознаки, учення про закономірності виникнення інформації про злочин і його учасників, про закономірності роботи з доказами, про злочин, учинення й приховування злочину тощо. При цьому, на

${ }^{1}$ Митричев B. C. Теория советской криминалистики (дискуссионная постановка вопроса о так называемых криминалистических учениях). Реферат научного сообщения на Х криминалистических чтениях. Москва : ВНИИСЭ, 1976. С. 9.

2 Образц̧ов В. А. Криминалистика : цикл лекций. Москва : Юрикон, 1994. С. 22; Його ж. Криминалистика : курс лекций. Москва : Право и Закон, 1996. С. 11.

3 Эксархопуло A. А. Зазнач. твір. С. 20; Криминалистика : учебник / под ред. Т. А. Седовой, А. А. Эксархопуло. СПб. : Изд-во ЛГУ, 1995. С. 18. 
думку автора, поряд із розвинутими криміналістичними теоріями слід виділяти менш розроблені та практично ще тільки позначені;

3) учення про методи криміналістики - методологія криміналістики у вузькому розумінні цього поняття;

4) учення про мову криміналістики - система понять і визначень, які використовуються в криміналістиці;

5) криміналістична систематика - принципи розподілу криміналістичних знань за розділами науки, починаючи від системи криміналістики в цілому, систем ії розділів і закінчуючи окремими криміналістичними системами та класифікаціями ${ }^{1}$.

Аналізуючи запропоновану структуру загальної теорії криміналістики, не можна не помітити, що в ній відбувається певне змішування різних за рівнем узагальнення теоретичних побудов, зокрема, учення про методи, про мову, криміналістична систематика мають відноситися до теорій загальнонаукової спрямованості, тоді як учення про механізм злочину, про закономірності виникнення інформації про злочин і його учасників, про закономірності роботи з доказами - до окремо наукових учень. Запропонована Р. С. Бєлкіним концепція не повною мірою відповідає критеріям розмежування загальної та окремих теорій як цілого й частини, на що автор, мабуть, теж звернув увагу, бо в наступних працях зробив відповідні корективи. В останній, за часом видання, роботі «Курс криміналістики» Р. С. Бєлкін пропонує більш широку структуру загальної теорії криміналістики, до числа елементів якої відносить:

1) положення, у яких формується уявлення про предмет криміналістики, іiї завдання, цілі та місце в системі наукового знання, поняття й зміст ії загальної теорії (перший розділ - вступ до загальної теорії криміналістики);

2) положення, які відбивають об'єктивні закономірності механізму злочину в аспекті криміналістики;

3) положення, які відбивають об'єктивні закономірності виникнення інформації про злочин і злочинця, закономірності збирання, оцінювання та використання доказів і є базою для розроблення криміналістичних засобів, методів та рекомендацій щодо використання доказів у практиці боротьби зі злочинністю, які зведені в чотири розділи:

а) криміналістичне вчення про закономірності виникнення інформації про злочин і злочинця;

б) криміналістичне вчення про закономірності збирання доказів;

в) криміналістичне вчення про закономірності дослідження доказів;

г) криміналістичне вчення про закономірності оцінювання та використання доказів.

Далі слідує система окремих криміналістичних учень: про навички; про спосіб вчинення й приховування злочинів; про механізм слідоутворення; про ознаки; про фіксацію доказової інформації; про криміналістичну реєстрацію;

1 Криминалистика : учебник. Т. 1 : История, общая и частные теории / под ред. Р. С. Белкина, В. Г. Коломацкого, И. М. Лузгина. Москва : Акад. МВД РФ, 1995. C. 39-41. 
про розшук; про версії та планування розслідування; про загальні принципи методики криміналістичних експертних досліджень; про причинність; про ідентифікацію; про прогнозування та ін. Компоновка структури завершується вченнями про методи й мову, а також про криміналістичну систематику, які складають три самостійних розділи ${ }^{1}$.

Ця архітектоніка загальної теорії криміналістики, безумовно, становила собою певний крок уперед і відрізнялася від конструкцій, що пропонувалися, як за формою, так і за змістом. Проте й вона не позбавлена відомих недоліків. По-перше, прагнучи не припуститися попередніх помилок, Р. С. Бєлкін виводить із системи окремих криміналістичних теорій вчення про механізм злочину, хоча називає останнє «положення, які відбивають об'єктивні закономірності в механізмі злочину в аспекті криміналістики», що, на нашу думку, навряд чи можна визначити більш вдалим. Крім того, із гносеологічної та етимологічної позицій говорити про «вчення про закономірності» взагалі не зовсім правильно, оскільки вчення (теорія) і є система знань про певну групу закономірностей об’єктивної дійсності. У зв'язку з цим доцільніше говорити про «криміналістичну теорію злочину», «криміналістичну теорію пізнання злочину», предметом дослідження яких і виступатимуть закономірності виникнення інформації про злочин і злочинця, а також закономірності збирання, дослідження, оцінювання та використання доказів. Результати пізнання перелічених закономірностей є базою як для формування й удосконалення інших окремих теорій певної спрямованості, наприклад, учень про версії й планування, фіксацію доказової інформації, слідчі ситуації та інших, так і для розроблення криміналістичних засобів, прийомів і рекомендацій із метою оптимізації процесу виявлення й розслідування конкретного злочину. По-друге, не зовсім зрозуміло, про які три самостійні розділи йдеться стосовно вчень про методи, мову та криміналістичну систематику й де ці розділи розташовуються в системі криміналістики.

Достатньо близькими до позиції Р. С. Бєлкіна можна визнати висловлювання М. В. Салтєвського щодо зазначеної проблематики, який до найбільш важливих у криміналістиці вчень відносить:

1. Учення про закономірності: а) механізму вчинення злочину; б) виникнення інформації та іiі джерел про злочин і його учасників; в) збирання й використання криміналістичної інформації в доказуванні.

2. Окремі криміналістичні теорії (учення): про навички; про ознаки та властивості; про спосіб учинення злочину; про версії й планування (версірування); про механізм слідоутворення; про систематизацію та реєстрацію криміналістичних джерел інформації; про збирання, зберігання, оброблення та автоматизоване використання інформації; про ідентифікацію й групування.

Перелік окремих криміналістичних теорій (учень), підкреслює автор, змінюється з розвитком науки криміналістики залежно від потреб практики боротьби зі злочинністю. Тому наведений перелік є приблизним².

1 Белкин Р. С. Курс криминалистики : в 3 т. Т. 1 : Общая теория криминалистики. Москва : Юристь, 1997. С. 56-60.

2 Салтевский М. В. Криминалистика. В современном изложении юристов : учеб. и практ. пособие. Харьков : Рубикон, 1997. С. 22. 
3. І. Кірсанов запропонував своєрідну структуру загальної теорії криміналістики, у якій окремі криміналістичні теорії диференціюються на два рівні: які $є$ елементами загальної теорії та які вивчаються в різних розділах криміналістики. До перших він відносить учення про механізм злочину та його відображення; учення про організацію діяльності щодо виявлення, попередження й розкриття злочинів і вчення про загальні методи криміналістики ${ }^{1}$. А. В. Іщенко взагалі поділяє теорії на фундаментальні (загальні) та прикладні. Якщо теоретичні побудови, констатує він, впливають на розвиток усієї науки, використовуються в усіх її складових (техніці, тактиці, методиці), то їх можна розглядати як фундаментальні. У разі, коли результати дослідження спрямовані на вирішення обмеженого кола питань, локального завдання, то їх слід розглядати як прикладні. Фундаментальними теоріями $€$ : загальна теорія криміналістики; теорія розвитку криміналістичної науки; учення про принципи криміналістики; учення про методи; учення про предмет; учення про мову; криміналістична теорія причинності; криміналістична теорія про механізм слідоутворення; криміналістична теорія про ознаку; криміналістична теорія організації роботи 3 доказами; теорія криміналістичної кібернетики та ін. ${ }^{2}$ О. Ю. Головін дійшов висновку про те, що найбільш прийнятною структурою загальної теорії криміналістики є така: наукознавчі основи криміналістики; методологічні основи криміналістики; система окремих криміналістичних теорій (учень) ${ }^{3}$. На думку В. Г. Лукашевича, посилення інтеграційних процесів у науці призводить до формування в рамках криміналістики окремих інтегративних теорій типу «теорії прийняття криміналістичного рішення», «теорії кримінальної (злочинної) та криміналістичної діяльності», «теорії виникнення інформації про злочин і його учасників», «криміналістичної теорії спілкування» та ін. ${ }^{4}$

Наведені позиції, безумовно, далеко не всі з числа тих, які висловлені в криміналістичній літературі щодо системи криміналістики взагалі та іiі загальної теорії зокрема, свідчать про те, що ця проблема залишається однією з найбільш дискусійних наукознавчих проблем. У зв'язку з цим уявляється за доцільне висловити деякі вихідні положення, які необхідно враховувати при здійсненні систематизації криміналістичних знань. По-перше, диференціація теоретичних побудов на загальні та окремі зумовлена передусім ступенем загальності відображуваних ними елементів об'єкта пізнан-

1 Кирсанов 3. И. Система общей теории криминалистики. Москва : Акад. МВД РФ, 1992. С. 8-10.

2 Іщзенко $A$. B. Методологічні та організаційні проблеми розвитку криміналістичних наукових досліджень : автореф. дис. ... д-ра юрид. наук : 12.00.09. Київ, 1996. C. 15.

Головин А. Ю. Криминалистическая систематика. Москва : ЛексЭст, 2002.

4 Лукашевич В. Г. Интеграция современного научного знания и тенденции построения частных криминалистических теорий. Теоретические и практические проблемы обеспечения раскрытия и расследования преступлений криминалистическими методами и средствами : сб. науч. тр. Киев : Укр. акад. внутр. дел, 1992. C. 6-17. 
ня, яким виступає або сама криміналістична наука, або подія злочину, або діяльність з розслідування злочинів. По-друге, теорія тільки тоді може претендувати на значення загальної, якщо вона поширюється на весь предмет науки, відображує його в цілому, а не один із його елементів. По-третє, сама загальна теорія як розділ криміналістичної науки являє собою системне утворення, яке включає як теорії загальнонаукового рівня, так і окремі наукові теорії. Аналіз характеру й особливостей існуючих інтертеоретичних зв'язків дає змогу зробити висновок про те, що між теоріями загальнонаукового рівня проявляється, головним чином, взаємозв'язок по горизонталі, тоді як для системи окремих наукових теорій (учень) більш специфічним $є$ вертикальний взаємозв'язок: теорія криміналістичної ідентифікації - теорія трасологічної ідентифікації - теорія дактилоскопічної ідентифікації. При цьому відношення підпорядкованості цілого й частини, що існують між предметом загальної теорії криміналістики та окремих криміналістичних теорій, виступають тим критерієм, котрий дозволяє віднести ту чи іншу теоретичну побудову до теорії певного рівня.

Слід також зазначити, що в криміналістичній літературі на сьогодні існують багато в чому протилежні точки зору й щодо розуміння самих окремих криміналістичних теорій (учень) і визначення їх місця в системі криміналістики. Погоджуючись у цілому з тим, що окремі криміналістичні теорії (учення) є складовою частиною загальної теорії криміналістики, передують останній або, навпаки, породжуються нею та досліджують тільки певне коло закономірностей об’єктивної дійсності з числа тих, які вивчає криміналістика в цілому, учені-криміналісти висловлюють різні підходи щодо обгрунтування можливості віднесення тих чи інших теоретичних побудов до рівня окремої криміналістичної теорії й визначення їх місця в системі криміналістики.

Дійсно, теоретична база криміналістики безперервно видозмінюється, поповнюючись теоріями різного ступеня зрілості, наукової та практичної значущості. На сьогодні можна стверджувати, що криміналістика, як і будьяка інша наука, являє собою систему теорій, оскільки, лише будучи системою теорій, наука здатна пояснювати різноманітні явища й зв'язки в сучасному та пророкувати хід розвитку в майбутньомуㄹ․ Зокрема, можна визнати завершеним розроблення криміналістичного вчення про потерпілого, криміналістичної класифікації злочинів, криміналістичної теорії тимчасових зв'язків і відношень при розслідуванні злочинів, криміналістичної теорії слідчих ситуацій, криміналістичної характеристики злочинів ${ }^{2}$ та ін. Зробле-

\footnotetext{
1 Штофф B. А. Проблемы методологии научного познания. Москва : Наука, 1978. C. 20.

2 Центров Е. Е. Криминалистическое учение о потерпевшем. Москва : Юрид. лит., 1988; Образцов В. А. Криминалистическая классификация преступлений. Красноярск, 1988; Мешков В. М. Криминалистическое учение о временных связях и отношениях при расследовании преступлений : автореф. дис. ... Д-ра юрид. наук : 12.00.09. Москва, 1995; Драпкин Л. Я. Основы криминалистической теории следственных ситуаций : автореф. дис. ... д-ра юрид. наук : 12.00.09. Москва, 1987;
} 
ні серйозні заявки про необхідність створення теорії криміналістичного об'єкта ${ }^{1}$, криміналістичної теорії причинності ${ }^{2}$, прогнозування ${ }^{3}$ та ін.

Водночас заявки й твердження про вже сформовану ту чи іншу нову теорію або необхідність створення такої мають бути максимально аргументованими з огляду на те, що далеко не всі теоретичні побудови можуть претендувати на рівень окремих наукових теорій. Так, В. О. Образцов пропонує створити «загальну» (курсив наш - В. Ж.) криміналістичну теорію взаємодії, наукова та практична потреба в якій відчувається все виразніше 4 . Уявляється, що таке становище частково пов'язане 3 достатньо вільним тлумаченням багато в чому дискусійної тези Р. С. Бєлкіна про те, що резерв системи (маються на увазі окремі теорії - В. Ж.) складають окремі теоретичні побудови або деякі сукупності таких побудов, ступінь консолідації яких може оцінюватися різно тим чи іншим дослідником. Від цієї оцінки залежить визнання подібної сукупності окремою криміналістичною теорією або заперечення такої якості ${ }^{5}$.

Зазначений підхід не сприяє вирішенню розглядуваних проблем, а, навпаки, породжує зайві дискусії. На нашу думку, усі нововведення, які претендують на статус «окремої криміналістичної теорії», мають співвідноситися з тими критеріями, які розроблені або потребують розроблення в криміналістиці. Нехтування ж цими критеріями призводить до суто суб'єктивного оцінювання, іноді без достатньої наукової аргументації, результатів наукового пошуку, до штучного механічного перенесення в загальну теорію таких теоретичних побудов, яким надано статус окремої криміналістичної теорії за власним бажанням того чи іншого науковця. До сумнівних теоретичних конструкцій можна віднести такі: «теорія криміналістичного програмування експертно-креативних систем» ${ }^{6}$, «теорія ускладненого безпосереднього пізнання», «теорія розпізнання» ${ }^{7}$, «криміналістич-

Колесниченко А. Н., Коновалова В. Е. Криминалистическая характеристика преступлений : учеб. пособие. Харьков : Юрид. ин-т, 1985 та ін.

1 Клочков В. В. Объект, предмет и система советской криминалистики. Предмет и система криминалистики в свете современных исследований : сб. науч. тр. Москва, 1988. C. 7-21.

2 Белкин Р. С. Курс советской криминалистики : в 3 т. Т. 3 : Криминалистические средства, приемы и рекомендации. Москва : Акад. МВД СССР, 1979.

3 Горшенин Л. Г. Основы теории криминалистического прогнозирования : монография. Москва : Акад. МВД РФ, 1993; Журавель В. А. Проблеми теорії та методології криміналістичного прогнозування : монографія. Харків : Право, 1999.

4 Образиов В. А. Проблема формирования понятия объекта криминалистики. Предмет и система криминалистики в свете современных исследований : сб. науч. тр. Москва, 1988. С. 37.

5 Белкин Р. С. Криминалистика: проблемы, тенденции, перспективы. Общая и частные теории. Москва : Юрид. лит., 1987. С. 144.

6 Зорин Г. А. Теоретические основы криминалистики. Минск : Амалфея, 2000. C. 19.

Криминалистика. Общая часть / под ред. В. Е. Корноухова. Москва : Юрист, 2000. C. 54-60. 
не вчення про знаряддя злочину (криміналістичне зброєзнавство)» , «криміналістична одорологія» ${ }^{2}$ та ін.

Щодо критеріїв, за якими доцільно оцінювати ту чи іншу теоретичну побудову з точки зору наявності в неї ознак теорії, то для їх визначення зроблені лише перші кроки. Так, Р. С. Бєлкін серед такого роду критеріїв насамперед виділяє загальні засади формування й обгрунтованість висновків $^{3}$. Крім того, як здається, кожна окрема криміналістична теорія повинна мати об'єкт, предмет і методи дослідження, розкривати їі зміст і характер стосунків з іншими теоріями (ученнями), визначати мету, завдання, функції та місце в системі криміналістики, формуватися на певній науковій гіпотезі, мати необхідне емпіричне підгрунтя, а також відповідний ступінь консолідації, що зумовлює можливість виділення певних закономірностей, які доповнюють, уточнюють предмет науки криміналістики в цілому.

Упорядкування криміналістичних теорій (учень), що входять до структури загальної теорії криміналістики, має здійснюватися з урахуванням таких положень:

- між предметами загальної теорії криміналістики та окремих криміналістичних теорій (учень) існують відносини підпорядкованості цілого й частини;

— кожна окрема теорія (учення) доповнює й уточнює предмет науки криміналістики, досліджуючи лише обмежене коло закономірностей із числа тих, які вивчає криміналістика в цілому. Так, Є. І. Зуєв зазначав, що окремі криміналістичні вчення уточнюють загальну теорію криміналістики, доповнюють ії новими даними ${ }^{4}$;

— характер закономірностей, які досліджує кожна зі створених криміналістичних теорій (учень), зумовлює порядок їх розподілу.

3 огляду на зазначене, убачається за доцільне в структурі загальної теорії криміналістики виділяти два блоки: 1) наукознавчі основи криміналістики, що включають окремі криміналістичні вчення (теорії) загальнонаукового рівня про об'єкт, предмет, методи, сферу дослідження, систему, природу, понятійний апарат і категорії криміналістики (мову криміналістики), іiі міжнаукові зв'язки й місце в системі знань, історію розвитку та сучасний стан; 2) криміналістичні вчення (теорії) окремонаукового рівня, які стосуються дослідження закономірностей, що входять до предмета дослідження криміналістики, розкривають його сутність і специфіку.

Як відомо, закономірності виявляються й формуються в основному на теоретичному рівні на підставі даних емпіричних досліджень усієї пред-

1 Образцов B. A., Хвалин B. A. О криминалистическом учении об орудии преступления. Тезисы Всерос. криминалист. чтений, посвящ. 100-летию со дня рожд. проф. А. Н. Васильева. Москва : МАКС Пресс, 2002. С. 104-108.

2 Басай В. Д. Основи криміналістичної одорології : автореф. дис. ... д-ра юрид. наук : 12.00.09. Київ, 2003. 31 с.

3 Белкин Р. С. Криминалистика: проблемы, тенденции, перспективы. Общая и частные теории. Москва : Юрид. лит., 1987. С. 145.

4 Зуев Е. И. Предмет, задачи, методы и система советской криминалистики. Криминалистика (актуальные проблемы). Москва, 1988. С. 15-18. 
метної галузі науки. Аналіз викладених у літературі позицій науковців дає змогу розглядати в найбільш загальному вигляді предмет криміналістики як систему взаємозв'язаних закономірностей двох рівнів: 1) закономірності виникнення, існування й зникнення інформації про механізм злочину (функціональну сторону кримінальної діяльності) і породжувані ним сліди; 2) закономірності одержання, дослідження, оцінювання й використання інформації про механізм злочину та породжувані ним сліди в процесі доказування.

Отже, криміналістичні теорії (учення) окремонаукового рівня мають поділятися на такі дві групи:

1. Криміналістичні теорії (учення) щодо механізму злочину:

— криміналістичне вчення про спосіб злочину;

— криміналістичне вчення про механізм слідоутворення;

— криміналістичне вчення про ознаки;

- криміналістичне вчення про навички;

- криміналістична віктимологія;

— криміналістична гомологія (учення про особу злочинця);

— криміналістичне вчення про часові зв'язки та відносини;

- криміналістична класифікація злочинів;

- криміналістична характеристика злочинів та ін.

2. Криміналістичні теорії (учення) пізнання механізму злочину:

- теорія криміналістичної ідентифікації;

— криміналістична теорія прогнозування;

- криміналістичне вчення про версію;

— криміналістична теорія планування та організації розслідування;

— криміналістична теорія фіксації доказової інформації;

- криміналістична теорія причинності;

- криміналістична теорія тактичних операцій;

— криміналістичне вчення про кримінальну реєстрацію та ін.

Наведений перелік окремих криміналістичних теорій (учень) не є вичерпним і остаточним, оскільки ці теорії (учення) постійно розвиваються, а зміни їх системи зумовлені такими чинниками: а) виникненням певних потреб у практиці боротьби зі злочинністю; б) розвитком суміжних галузей знань і їх інтеграцією чи диференціацією; в) розвитком загальної теорії криміналістики як результат проникнення в сутність предмета науки; г) розвитком самих окремих криміналістичних теорій, зміною зв'язків і залежностей між ними ${ }^{1}$.

Висновок. Отже, розв'язання цих та інших проблем є необхідною умовою успішного розроблення концептуальних підходів до формування окремих криміналістичних учень (теорій) різного рівня і спрямованості, які в сукупності становлять основу загальної теорії криміналістики як системи засадничих положень здійснення наукового пошуку в цій царині знань.

1 Клименко Н. И. Общая и частные криминалистические теории. Ученые записки Таврического нац. ун-та им. В. Н. Вернадского. Серия «Юрид. науки». 2013. T. 26 (65). № 1. C. 231. 


\title{
ЧАСТНЫЕ УЧЕНИЯ В СТРУКТУРЕ ОБЩЕЙ ТЕОРИИ КРИМИНАЛИСТИКИ
}

\author{
Журавель В. А.
}

Рассмотрены концептуальнье подходы к формированию и реализачии частных криминалистических учений (теорий) как научных конструкций, составляющих основу структуры общей теории криминалистики и определяющих уровень разработки теоретико-методологической базы этой науки. Дано авторское понимание понятия «частное криминалистическое учение (теория)», и высказаны предложения по систематизации частных криминалистических учений, их места в структуре общей теории криминалистики. Предложено в структуре общей теории выделять два блока: 1) научные основы криминалистики, которые включают в себя частные криминалистические учения (теории) общенаучного уровня об объекте, предмете, методах, сфере исследования, системе, природе, понятийном аппарате и категориях криминалистики (языке криминалистики), ее связях с другими науками и месте в системе знаний, истории развития и современном состоянии; 2) криминалистические теории (учения) отдельного научного уровня, которые касаются исследования закономерностей, которые входят в предмет исследования криминалистики, раскрывают его сущуность и специфику. Подчеркнуто, что характер закономерностей, которые исследует каждое из частных криминалистических учений (теорий), обусловливает порядок их упорядочения в структуре общей теории. При этом между предметами общей теории криминалистики и частных криминалистических учений (теорий) существуют отношения подчиненности целого и части. Отмечено, что современная система частных криминалистических учений (теорий) динамична и ее усовершенствование обусловлено нуждами судебной и следственной практики, развитием смежных областей знаний, общей теории и самих частных криминалистических учений, изменением связей и зависимостей между ними. Определены критерии, которым должно отвечать частное криминалистическое учение (теория). В частности, обращено внимание на то, что каждое частное криминалистическое учение (теория) должно иметь объект, предмет и методы исследования, раскрывать его содержание и характер отношений с другими учениями (теориями), определять ичель, задачи, функции и место в системе криминалистики, формироваться на определенной научной гипотезе, иметь необходимую эмпирическую основу, а также соответствующую степень консолидации, которая предопределяет возможность выделения определенных закономерностей, дополняюших, уточняюших предмет науки криминалистики в иелом. Обозначены дискуссионные вопросы в исследуемой проблеме, очерчены пути оптимизации научных разработок в этой области знаний.

Ключевые слова: общзая теория криминалистики, структура общей теории криминалистики, частные криминалистические учения (теории), систематизация частных криминалистических учений (теорий).

\section{SPECIFIC STUDIES IN THE STRUCTURE OF GENERAL CRIMINALISTIC THEORY}

\section{Zhuravel V.A.}

Conceptual approaches to formation and application of certain criminalistic doctrines (theories) as scientific constructions forming the basis of criminalisctic general theory structure and developing the level of theoretical and methodological basis of this science 
are considered. The author's opinion of Specific Criminalisctic Doctrine (Theory) concept is offered and proposals are made regarding systematization of specific criminalisctic studies, their place in the structure of the criminalistic general theory. It is proposed to allocate two blocks in the structure of the general theory: 1) criminalistic science based essentials including specific criminalistic doctrines (theories) of general scientific level about object, subject, methods, scope of research, system, nature, conceptual apparatus and criminalistic categories (Criminalistic language), its interscientific relations and place in the system of knowledge, development history and the present state; 2) criminalistic theories (doctrines) of a separate scientific level relating to research of patterns that are part of the research subject of criminalistics reveal its essence and specifics. It is emphasized that regularity nature exploring each of specific criminalistic doctrines (theories) determines the order of their ordering in the structure of general theory. Thus between subjects of general criminalistic theory and specific criminalistic doctrines (theories) there are relations of subordination of the whole and part. It is noted that modern system of specific criminalistic doctrines (theories) is dynamic and its improvement is conditioned by the needs of judicial and investigative practice, by the development of related knowledge branches, by the general theory and the most specific criminalistic doctrines, by the relation change and relationships between them. Criteria that should correspond to a specific criminalistic doctrine (theory) are defined. In particular, attention was drawn to the fact that each specific criminalistic doctrine (theory) should have object, subject and research method, reveal its content and nature of relations with other doctrines (theories), define the purpose, tasks, functions and place in criminalistic system, be formed on a certain scientific hypothesis, have necessary empirical basis, as well as the corresponding degree of consolidation determining the possibility of identifying certain regularities expanding and clarifying the subject of criminalistic science in general. Controversial issues regarding this problem are separated; optimizing scientific development ways in this field of knowledge are outlined.

Keywords: general criminalistic theory, structure of general criminalistic theory, specigic criminalistic doctrines (theories), systematization of specigic criminalistic doctrines (theories).

DOI: https://doi.org/10.32353/khrife.2018.03

УДК 343.98

В. М. Шевчук, професор кафедри криміналістики Національного юридичного університету імені Ярослава Мудрого, доктор юридичних наук, професор, заслужений юрист України E-mail: shevchuk_viktor@ukr.net

\section{МІСЦЕ ТАКТИЧНИХ ОПЕРАЦІЙ У СИСТЕМІ КРИМІНАЛІСТИКИ}

Досліджено проблеми з'ясування місия тактичних операцій у системі криміналістики та процесі кримінального провадження. Доведено, щзо при розв 'язанні цього питання необхідно виходити з природи тактичних операиій, перспектив їх розвитку, а також специфіки взаємозв'язку криміналістичної тактики й методики розслідування окремих видів злочинів. Роз- 